\title{
Multinational activity of European firms and heterogeneity
}

Autores y e-mail de la persona de contacto:

José C. Fariñas (farinas@ccee.ucm.es; Universidad Complutense Madrid)

Ana Martín-Marcos (UNED)

Francisco J. Velázquez (Universidad Complutense Madrid)

Departamento: Economía Aplicada y Fundamentos Análisis Economico

Universidad: UCM y UNED

Área Temática:

Sector exterior, inversión directa extranjera y flujos interregionales

\section{Resumen:}

This paper offers an empirical assessment of the multinational activity of European firms. It takes the predictions of models of firm heterogeneity and FDI activity as a reference to explore the characteristics of multinational firms from 30 European countries. We use an original dataset, based on ORBIS, which links information of parent-affiliate pairs of firms. Our results show that more productive firms have greater multinational activity in terms of both scope, the number of foreign markets where they invest, and scale, the volume of local sales by subsidiaries active in foreign markets. The estimation of gravity equations shows that country characteristics that encourage multinational activity successively induce the entry of less productive parent firms. We confirm this asymmetry for the following variables: GDPs of the home and host countries, distance, contiguity and having a common colonial history. )

Palabras Clave: Foreign Direct Investment, Firm heterogeneity, Multinational corporations

Clasificación JEL: F23, L25, M16 


\section{Introduction}

This paper offers an empirical assessment of the multinational activity of European firms. It takes the predictions of models of firm heterogeneity and FDI activity (see Antràs and Yeaple (2014) for a recent state of the literature) as a reference to explore empirically basic characteristics of multinational firms from 30 European countries. This analysis uses an original dataset, based on ORBIS, which links information of parent-affiliate pairs of firms. To organize our empirical work, we take Yeaple (2009) as a reference. This model derives from Helpman, Melitz and Yeaple (2004) and combines two approaches to the analysis of multinational activity: first, the proximityconcentration model of Brainard (1997), where firms face a trade-off between transport costs with trade and fixed investment costs with foreign investment, and second, the heterogeneity model of Melitz (2003), where firms differ in their productivity levels.

Our research concentrates on two sets of predictions. The first one refers to the factors that influence the scope and the scale of multinational activity. According to these models, there is a country-specific cutoff productivity level which determines both the number of foreign affiliates a firm opens in foreign markets (scope) and the size of operations of these affiliates (scale). The second prediction refers to the country characteristics, both of the home and the host country, that influence the productivity cutoff and therefore the decisions that characterize the structure of multinational activity that we observe across countries.

With respect to the first prediction, Helpman, Melitz and Yeaple (2004) have shown the existence of a sorting pattern between exporting firms and firms that engage in FDI, the latter being the most productive group relative to both exporters and firms serving the domestic market. Yeaple (2009) shows that this kind of sorting also extends to the scope and scale of multinationals: more productive parent firms operate in a higher number of foreign markets and at a higher scale in terms of the average sales of their subsidiaries. We test for the existence of this sorting, taking a large sample of European multinationals as a reference. This analysis considers two perspectives. The first one concerns the scope of multinational activity. We estimate the probability of investing in a foreign market as a function of parent firms' productivity. The second one concentrates on the scale of the multinational activity. In particular, we examine the 
relationship between the size of subsidiary firms, measured in terms of sales in foreign markets, and their parent firms' productivity.

Concerning the second prediction about country characteristics, it is common in the literature of gravity equations to estimate the effect of country characteristics on aggregate flows of FDI activity, using either bilateral flows of FDI or aggregate sales as well as the number of affiliate firms operating in foreign markets as dependent variables (Brainard, 1997; Kleinert and Toubal, 2010). An important feature of Yeaple (2009) is that country characteristics determine the productivity cutoff which drives the investment entry decision of firms in foreign markets. Therefore, the productivity composition of firms with a multinational activity is influenced by the characteristics of countries where they invest. This is the second prediction we examine. More specifically, we test whether country characteristics that are associated in one direction with the volume of multinational activity are related to the productivity levels of parent firms investing abroad in the opposite direction. In short, country characteristics that encourage a greater volume of multinational activity induce the entry of successively less productive firms. If this happens, country characteristics that positively affect the volume of multinational activity, defined in terms of the value of affiliates' production in foreign markets across two countries, should be negatively associated with the level of productivity of the least productive parent firm entering the host country.

The paper offers a general overview of the multinational activity of European firms from the perspective of the previous two sets of predictions. We build an original dataset, based on ORBIS, which links information of parent firms and their affiliates. The sample contains parent firms with a manufacturing ISIC code as their principal activity and have at least one affiliate firm operating abroad that is also active in a manufacturing activity. The sample has 15,055 multinational parent manufacturing firms from 30 European countries, and these multinationals are immediate owners of 55,583 manufacturing subsidiaries operating in 183 host countries.

To our knowledge, this is the first time an empirical analysis of these characteristics has been applied to examine the features of the multinational activity of European manufacturing firms. The features covered in the analysis refer to two aspects: the hypothesis linking productivity to the scope and the scale of multinationals, and the asymmetric effect hypothesis which links, with opposite signs, country characteristics to 
the scale of multinational operations and their average productivity. As the sample of firms is representative of the population of European multinational firms, the analysis offers a portrait of relevant aspects that have recently been highlighted by models of firm heterogeneity and FDI activity.

This paper makes at least three additional contributions. First, the links between parent and subsidiary firms are defined with the notion of "property" (the parent firm is an immediate owner of the subsidiary firm), and the notion of "control" (the parent firm is the ultimate owner of the subsidiary). We check whether results are sensitive to the use of both criteria. Second, the scope and scale elasticities of firms' multinational activity are estimated for the aggregate sample of European firms and also for individual countries (France, Germany, Italy and Spain). Differences across countries in the intensity of the relationship between firm characteristics and the scope and scale of the multinational activity of firms have not yet been considered in the literature. Third, we extend the use of statistical techniques not frequently applied in this research area, in particular, the use of count data models to examine the decision to open a subsidiary in a foreign market. Besides this, the issue of excess zeros has been taken into account when estimating gravity equations and running regressions on the scope of multinational activity.

The results the paper shows are similar to those observed for US multinationals by Yeaple (2009). First of all, we confirm a positive relationship between a parent's productivity and the number of subsidiaries per country as well as the scale of operation of their subsidiaries. There is more heterogeneity across scale elasticities for different countries than for scope elasticities, which probably reflects differences in the strategy of multinational firms across European countries. Secondly, concerning the asymmetric effect hypothesis, we show that for five standard gravity variables (GDPs, distance, contiguity and common colonial history) the (+/-) effect of a specific country characteristic on the level of multinational activity has the opposite effect for the level of productivity of the least productive parent multinational entering a foreign market.

The paper is organized as follows. Section 2 presents the characteristics of the dataset used in the paper along with the measurement issues. Section 3 reports the results related to the scope and scale analysis. We use both a linear probability model for comparative purposes with previous papers and count data models to examine the 
dependent variable: number of subsidiary firms a parent firms has in a given market. Section 4 presents the results related to the asymmetric effect hypothesis between the scale of multinational firms and their productivity. In this section, we present various gravity equations that pay attention to multilateral resistance issues and to observations with zeros in aggregate bilateral flows between countries. Section 45 concludes.

\section{Data and measurement}

The data used in this paper is taken from ORBIS database of Bureau Van Dijck. ORBIS contains the information from company accounts or business records on more than 164 million companies or business records around the world. This corporate database provides information on financial accounts and the ownership structure of firms from both the perspective of shareholders and the point of view of affiliated companies. All the information we obtain from ORBIS refers to the year 2011.

Although ORBIS is a collection of business records rather than a comprehensive business register, it is suited for the analysis of multinational activity since it provides business information on a number of key variables and has a good coverage for the set of largest manufacturing companies in the OECD. An effective way to assess the representativeness of the ORBIS dataset for our purpose is to compare the number of companies available in this dataset with the number of companies recorded by the OECD Structural and Demographic Business Statistics (SDBS), which is based on official business information provided by the statistical offices of OECD countries. Table A1 in the Annex compares the number of large firms with 250 or more employees in the manufacturing sector in both datasets: ORBIS and SDBS. We take the class size of large firms as a reference because they are the main actors of multinational activities and our main population target (BarbaNavaretti and Venables, 2005). Representativeness is quite high, with a few exceptions. The ratio between the number of firms in ORBIS and the number in SDBS is for most countries larger than $70 \%$. For more details on the representativeness of ORBIS, see Pinto-Ribeiro, Menghinello and Backer, (2010).

From ORBIS we construct a sample of world-wide manufacturing affiliate firms that are majority owned by a European parent company whose main sector is a 
manufacturing industry. Papers that have used similar information to examine FDI activity include Engel, Proecher and Schmidt (2013), which examines foreign entry of French firms, and Marti, Alguacil and Orts (2015) for seven European countries. To determine whether an investment can be considered FDI, the OECD (2005) recommends classifying an enterprise within a country on the basis of the presence or absence of effective foreign participation in its capital. If a majority of ordinary shares (more than 50 percent of the capital) is held by a single foreign investor, then we refer to this as FDI. Following this consideration, we define two criteria to identify links between a parent firms and its foreign affiliates. The first one is based on the use of the notion of "immediate property" to determine whether a firm is a parent-multinational along with the set of affiliates firms which are linked to each parent company. Following this notion, our sample of firms considers a parent-multinational firm to be a firm which is a direct or immediate owner of at least one affiliate in a foreign country. Similarly, an affiliate firm is defined as an incorporated enterprise in which a nonresident investor owns more than 50 percent of the capital.

The second approach coincides with the notion of "ultimate control" (OECD, 2005), where the affiliate companies are under the ultimate control of a parent firm. Under this approach, affiliate firms abroad are controlled directly and indirectly. The condition for defining the path from the affiliate company to its ultimate owner requires the parent firm to own more than $50 \%$ of the capital of the subsidiary at every step.

The objective of using two approaches to identify links between firms is to check for robustness considering two alternative definitions of parent firms: companies that are immediate owners of affiliate firms abroad and firms that are global ultimate owners of foreign affiliates. According to the first criterion, the link between the parent and the affiliate firm is based on a notion of property, i.e., immediate property. With this criterion, there is no guarantee that ultimate control is based on a European firm. The second criterion ensures that the subsidiaries are controlled by European firms.

Given the two criteria, the sample contains two types of firms: parent multinational firms with a manufacturing ISIC code as the principal activity, and which have at least one affiliate operating abroad and their affiliate firms active in a manufacturing sector. We take the group of countries that are members of the European Economic Area as a reference. Membership of this agreement is open to member states of the European 
Union and the European Free Trade Association. The set of multinational firms included in the sample is controlled by residents of 30 different countries: Austria, Belgium, Bulgaria, Cyprus, the Czech Republic, Germany, Denmark, Estonia, Spain, Finland, France, the United Kingdom, Greece, Croatia, Hungary, Ireland, Iceland, Italy, Lithuania, Luxemburg, Latvia, Malta, the Netherlands, Norway, Poland, Portugal, Romania, Slovenia, Slovakia and Sweden. Because of a lack of information, we exclude Liechtenstein from the list of countries of the European Economic Area.

Table 1 summarizes the characteristics of the sample of firms and countries used in the analysis. It reports information from the sample based on the immediate owner criterion and the one based on the global ultimate owner criterion. ORBIS identifies a total number of 15,055 multinational parent manufacturing firms from 30 European countries. These firms are immediate owners of a group of 55,007 manufacturing subsidiaries operating in 183 host countries. This is the maximum number of firm-pairs observations that ORBIS identifies. The second sample, defined in column (b), considers host countries that have at least 50 subsidiary firms. This reduces the number of firms by a very small amount: $0.8 \%$ of parent firms and $2.6 \%$ of subsidiary firms. The main advantage of using this sample is the reduction of the number of potential markets from 183 to 71 host countries. This substantially reduces the number of zero entries in potential markets and the intensity of estimation issues associated with zero inflated effects. For this reason, we take the sample of column (b) as our baseline sample for estimations, although we report some robustness checks with the sample defined in column (a). Finally, ORBIS identifies links between firms, but in some cases, there is no financial information for the firms themselves. Column (c) reports the number of firms in the sample conditional on the fact that the value of sales for the parent firms has to be available in ORBIS. The reduction in the number of observations of sample (c) is approximately $20 \%$ with respect to sample (a).

Table 1 also provides information on the three samples obtained when the link between parent and subsidiary firms is defined using the criterion of global ultimate owner. As the figures show, there is a reduction in the number of firms. When parent firms are global ultimate owners, samples have approximately $20 \%$ fewer firms. This reduction is basically due to the fact that more information is required to complete the entire 
sequence of direct and indirect participations in capital. As we mention before, our objective is to check for robustness using both criteria.

Concerning the variables used in the analysis, a first set of results refers to the scope and scale of multinational firms. The basic source of this analysis is ORBIS and the set of variables is defined as follows:

Gross Output: measured in ORBIS by Operating revenue turnover.

Employment: Total number of employees

Labor productivity: Gross Output/Employment.

Concerning the variables included in the gravity equations, the basic variables (GDP, distance, etc.) came from two sources: the World Bank and the GeoDist database from CEPII (T. Mayer and S. Zignago, 2011). The definition of this group of variables is as follows:

GDP $_{\mathrm{i}}$ : GDP of the European country where the parent firm is located.

GDP $_{\mathrm{j}}$ : GDP of the country where the affiliated firm is located.

DIST $_{\mathrm{ij}}$ : Bilateral distance between countries, calculated following the great circle formula, which uses the latitudes and longitudes of the most important cities/agglomerations.

CONTIG $_{\mathrm{ij}}$ : Dummy variable indicating whether the two countries are contiguous.

COMLANG $\mathrm{ij}_{\mathrm{ij}}$ : Dummy variable indicating whether the two countries share a common language.

COMCUR $\mathrm{ij}_{\mathrm{ij}}$ : Dummy variable indicating whether the two countries share a common currency.

$\mathrm{COMCOL}_{\mathrm{ij}}$ : Dummy variable indicating whether the two countries have ever had a colonial link.

Table 2A in the Annex shows the descriptive statistics of the previous list of variables. 


\section{The scope and scale of multinational activity}

In this section, we report two different types of results. The first set of results is related to the scope prediction of multinational activity: more productive firms have greater multinational activity. We examine this prediction by taking the foreign investment behavior of individual European manufacturing firms as a reference. The second set of results examines the scale hypothesis: the relationship between the affiliate's local sales in foreign markets and its parent firm's productivity.

\subsection{Scope}

First we provide estimations of the propensity of European firms to invest in any given foreign country as a function of the parent firm's productivity. Following Yeaple (2009), and for ease of comparison, we start with a simple linear probability model. The specification is:

$$
D N_{f t t}=\beta_{1} l n L P_{f t j}+\theta_{s}+\theta_{t}+\theta_{t}+\varepsilon_{f t t}(1)
$$

where $D N_{f t t}$ is a variable equal to one if a parent firm $f$ from country $i$ has one or more subsidiary firms in country $j$ and zero otherwise; $L n L P_{f t j}$ is the natural logarithm of labor productivity of the parent firm from country i investing in country $\mathrm{j}$; $\theta_{s}$ represents sectorial fixed effects captured by industry dummies defined at the four-digit level; $\theta_{t}$ represents home country fixed effects and $\theta_{j}$ host country fixed effects.

Table 2 presents the results of the estimation of equation (1) by OLS. On the left-hand side panel of Table 2, parent firms from country $i$ are immediate owners of subsidiary firms in country $\mathrm{j}$, in both cases in the manufacturing sector. On the right-hand side panel of Table 2, similar estimates of equation (1) are presented for parent firms that are global ultimate owners of foreign affiliates. Both concepts, immediate owner and global ultimate owner, have been defined in Section 2.

Parent firm size as proxied by sales is positive and significant, indicating that larger multinational firms are more likely to own an affiliate in any given country. The magnitude of the coefficient, 0.01 , indicates that a $1 \%$ increase in size raises the probability of opening a subsidiary in a new foreign market by 0.0001 points. To give 
an intuition of this magnitude, doubling the size of the firm increases the probability by 0.01 points, and given that the average probability is around 0.04 , doubling the size increases the probability by $25 \%$. The coefficient is slightly lower than the coefficient reported by Yeaple (2009) for US multinationals, where the magnitude of the coefficient is 0.03 .

The results presented in columns 2 of Table 2 correspond to the specification using the logarithm of parent firms' labor productivity as the explanatory variable. Although size is a sufficient statistic for productivity in standard models of heterogeneous firms (Melitz, 2003), here we also include a direct measure of firm productivity. This measure is positive and statistically significant, indicating that more productive firms are more likely to own an affiliate in a given foreign country. The coefficient is slightly lower than the one reported for size measured with firm sales.

Previous estimations are repeated in the right-hand side panel of Table 2. This time the link between parent and affiliate firms is defined with the criterion of global ultimate owner. Results are very similar and the magnitude of the coefficients is larger using the criteria of global ultimate owner instead of using the criteria of immediate owner. Although it is difficult to interpret this difference as the composition of both samples is different, it might be reflecting the fact that in the sample where parent firms have ultimate control over affiliates, we are able to better capture the decisions linking both groups of firms.

A natural alternative to the estimation of equation (1) is to consider the number of subsidiary firms a parent firm has in a given market as the dependent variable. As Figure 1 suggests, our sample of observations is concentrated on a few small discrete values, mainly 0,1 and 2 . The 12,057 parent firms in the sample and the set of possible host country destinations make a total sample of 843,994 observations. Of these, $96 \%$ are zeros (no single subsidiary owned by firm $f$ from home country $i$ opens a subsidiary firm in host market $j$ ), $3 \%$ corresponds to firms with one subsidiary, $0.6 \%$ corresponds to two subsidiaries and the rest correspond to a few additional integers.

Given that the response variable is discrete, the distribution places probability mass at non-negative integer values only, and the sample concentrates on a few small discrete 
values, the natural place to start are count data models (see Cameron and Trivedi, 2005). Therefore, our basic specification is:

$$
N_{f t i}=\exp \left(\beta_{1} \ln L P_{f t i}+\theta_{s}+\theta_{t}+\theta_{j}\right)+\varepsilon_{f t t}
$$

where $N_{f t y}$ is the number of subsidiary firms owned by a parent firm $f$ from country $i$ in market $j$, and the left-hand side variables are the same as in equation (1). This is the classical Poisson regression model.

Two issues associated with the estimation of equation (2) are considered (see Miguélez and Moreno, 2013, for a similar application in the geography of innovation). The first issue refers to the assumption Poisson regression makes: the mean and the variance are the same. For count data, the variance usually exceeds the mean, a feature called overdispersion. The consequence of over-dispersion is the underestimation of standard errors (Cameron and Trevidi, 2005). The strategy to address over-dispersion is to modify the Poisson model, estimating a Negative Binomial regression. The second issue is termed the excess zeros problem, when there are more zeros in the data than the Poisson predicts. In this case, a modified model is called the zero inflated model, both in the Poisson version (ZIP) and the Negative Binomial (ZINP). These latter models complement a count density with a binary process. If the binary process takes the value 0 , then our count variable is $N=0$, and if the binary process takes the value 1 , then variable $\mathrm{N}=1,2, \ldots$ (Cameron and Trevidi, 2005). Table 3 reports four estimations that correspond respectively to the Poisson and the Negative Binomial models (PML and NBML) and to their zero inflated versions: Zero Inflated Poisson (ZIPML) and Zero Inflated Negative Binomial (ZINBML).

Table 3 reports various over-dispersion tests. The first one corresponds to the direct estimation of parameter $\alpha$ incorporated into the Negative Binomial. In both columns two and four, the coefficient $\alpha$ is significantly different from zero. The second test is the LR test of $\alpha=0$, which largely rejects the null hypothesis of no over-dispersion. Therefore, both tests lead to the conclusion that the Negative Binomial models are preferred to Poisson models.

Vuong statistics are also reported for the zero inflated versions of both Poisson and Negative Binomial models. Both tests point to the preference for zero inflated versions 
given the high proportion of zeros in our dataset. Therefore, statistical tests point out that column (4) reporting the ZINBML is the preferred specification for examining the influence of parent productivity on the count variable: $N_{f t t}$.

In the upper part of column (4), Table 3, the elasticity between parent firm productivity and the number of subsidiaries entering a given foreign market appears (as the variable is expressed in logarithms, the estimated coefficient can be interpreted as an elasticity, Cameron and Trevidi, 2005). According to the estimator, a 1\% increase in a firm's productivity increases the number of subsidiaries abroad by $0.1 \%$.

Column (4) also reports the estimation for the complementary model predicting zeros. For this auxiliary equation the following three variables are included as explanatory variables: the Total number of subsidiary firms owned by firm $f$, the GDP of host country and the Distance between the home and the host countries. The signs of the estimated coefficients are as expected (notice that as the model is predicting zeros, the sign of the coefficients goes in the opposite direction relative to the usual presentation). The higher the total number of subsidiaries owned by the parent firms and the higher the level of the host country's GDP, the lower the probability of observing zero subsidiaries in a given host country. With respect to distance between the home and the host countries, a positive effect is obtained, as expected.

Overall, the results presented suggest that for European multinational firms, the number (scope) of their affiliate firms is positively influenced by the size and the productivity of their parent firms. These results are similar to those obtained for US multinationals by Yeaple (2009). Figure 2 summarizes this strong relationship between a parent firm's productivity and the number of subsidiary firms it owns. This positive relationship is also very intense for the size of parent firms.

Figure 3 draws a scatter diagram across countries on the relationship between average firm productivity of multinationals and the average number of subsidiary firms. As expected, this relationship is positive: countries with a higher average productivity of their parent multinationals have a higher average number of subsidiaries per firms in a given market. Figure 3 suggests that a certain degree of heterogeneity across countries might exist in the elasticity between productivity and the number of subsidiaries. Next, we present some evidence related to this question. 
Table 4 reports the elasticities estimated for four different European countries: France, Germany, Italy and Spain. We choose this group of countries because they have a large number of parent and subsidiary firms, and have good coverage in ORBIS. The elasticities are obtained by estimating equations (1) and (2) with the observations of parent firms from each country and their subsidiaries. All estimates are obtained using the criteria of immediate owner to define the link between parent and subsidiary firms. The upper panel of Table 4 reports the elasticities for the dependent variable $D N_{i j}$. The most interesting result from Table 4 is the existence of systematic differences across countries in the magnitude of these elasticities between the level of firm productivity and the number of subsidiaries owned in foreign markets. Taking the linear probability model as a reference, the country with the highest elasticity is Germany, followed by France, Italy and, finally, Spain.

Very similar results are obtained when estimating the elasticities, not in terms of the probability of opening a subsidiary abroad, but in terms of the number of subsidiaries abroad in a given market $\left(N_{i j}\right)$. The lower panel of Table 4 reports the zero inflated versions of Poisson (ZIPML) and Negative Binomial (ZINBML) estimators. In general terms, both estimators reproduce differences across countries which are very similar to those reported for the linear probability model, especially in terms of the ranking across countries.

\subsection{Scale}

The second set of results concerns the scale of multinational activity. The objective here is to examine the relationship between the scale of operations of multinational firms, in terms of a subsidiary's sales in the host country, and the productivity of the parent firms. The specification is:

$$
\ln S_{f t t}=\beta_{1} \ln L P_{f t t}+\theta_{s}+\theta_{t}+\theta_{t}+\varepsilon_{f t t}
$$

where $S_{f t t}$ is the level of aggregate sales in market $j$ of subsidiary firms owned by a parent firm $f$ from country $i$, and the right-hand side variables are the same as in equation (2).

The presentation of results follows a pattern similar to those in previous section. Table 5 offers the main results. The first row shows the results of regressing the logarithm of the 
foreign affiliate's sales on the logarithm of the parent firm's sales. Controls for industry and country fixed effects are included. In the case of country effects, we control for both the country of origin of the foreign investment and the country of destination. The estimated elasticity across all European parent and subsidiary firms implies that for a $1 \%$ increase in the size of the parent firm, the size of the affiliate increases by almost $0.3 \%$.

The second row shows the results when a direct measure of the parent firm's productivity is included in the right-hand side of equation (3). The coefficient is statistically significant and indicates that the size of affiliate firms is increasing in their parent productivity. The magnitude of the elasticity is similar, 0.3 , to the elasticity obtained for parent firm size.

The right-hand side panel of Table 5 repeats previous estimations, taking into consideration that parent firms are global ultimate owners of subsidiary firms instead of immediate owners. Results are very similar to those obtained when the parent firm is an immediate owner of the subsidiary firm.

Do we find a similar positive relationship between the labor productivities of parent and subsidiary firms? We do not report the results in Table 5, but this hypothesis is confirmed. The positive relationship between the scale of operations of subsidiary firms and their parent firms' productivity also extends to the relationship between the productivity of both parent and subsidiary firms. Coefficients remain positive and significant when introducing controls for industry and country fixed effects.

As in the previous section, we report the elasticities estimated for the group of four countries: France, Germany, Italy and Spain. Table 6 reports these elasticities. There is more heterogeneity across scale elasticities than across scope elasticities. Estimated values range from 0.49 to 0.15 when using labor productivity of the parent firms. These differences across countries might be reflecting differences in the strategy of multinational firms. Surprisingly, the lowest estimated value corresponds to Germany, indicating that the scale of foreign subsidiaries is lower for a given size and productivity of parent firms relative to the rest of the countries considered in Table 5. 
Overall, the results presented in this section suggest that the size (scale) of European multinational firms' affiliate firms is positively influenced by the size and the productivity of their parent firms. These results are similar to those obtained for US multinationals by Yeaple (2009). We find significant heterogeneity across countries in the estimated elasticities.

\section{Country characteristics and the structure of multinational activity}

\section{(this section has not been included)}

\section{Conclusions}

This paper offers an empirical assessment of the multinational activity of European firms. It takes the predictions of models of firm heterogeneity and FDI activity as a reference to empirically explore some basic characteristics of multinational firms from 30 European countries. We use an original dataset, based on ORBIS, which links information of parent-affiliate pairs of firms.

These results are similar to those observed for US multinationals by Yeaple (2009). Concerning scope elasticity, the relationship between a parent's productivity and the number of subsidiaries per country, we estimate that doubling the size of the firm increases the probability by 0.01 points, and given the average probability, this implies an increase of $25 \%$. This is an average value across European firms with multinational activity. The estimation of this elasticity for individual countries shows the existence of systematic differences across countries. Concerning scale elasticity, an increase of $1 \%$ in parent firms' productivity increases affiliate sales in foreign markets by $0.3 \%$. There is more heterogeneity across scale elasticities for different countries than for scope elasticities. This might be reflecting differences in the strategy of multinational firms across European countries.

A second set of results refers to the relationship between country characteristics and the structure of multinational activity. We estimate gravity equations with the objective of testing the basic prediction that those country characteristics that positively (negatively) affect the level of multinational activity, in terms of subsidiary sales, should be negatively (positively) associated with the level of productivity of the least productive 
parent firm entering the market. In short, country characteristics that encourage multinational activity successively induce the entry of less productive parent firms. We confirm this asymmetry for five standard gravity variables: the GDP of the host country, the GDP of the home country, the distance between home-host countries, the existence of contiguity (sharing a common land border) and sharing a common colonial history.

Our results are robust to the control of 'multilateral resistance' when estimating gravity equations. Although in this case we have to restrict ourselves only to the consideration of bilateral country characteristics, we confirm that distance, contiguity, common colonial history and common language appear, respectively, with opposite signs $(+/-)$ in the sales and the productivity equations. 


\section{References:}

Antrás, P. and S. R. Yeaple (2014), "Multinational Firms and the Structure of International Trade", Handbook of International Economics, 4, pp. 55-130.

Anderson, J. E. and E. van Wincoop (2003), "Gravity with Gravitas: A solution to the Border Puzzle", American Economic Review, 93, pp 170-192.

Barba Navaretti, G. and A. J. Venables (2006), Multinational Firms in the World Economy, Princeton University Press.

Berden, K. J. H. Bergstrand and E. van Etten (2014), "Governance and Globalization", The World Economy, 37(3), pp. 353-386.

Brainard, S. L. (1993) "A Simple Theory of Multinational Corporations and Trade with a Trade-Off Between Proximity and Concentration”, NBER Working Paper No. 4269.

Brainard, S. L. (1997), "An Empirical Assessment of the Proximity-Concentration Trade-Off Between Multinational Sales and Trade," American Economic Review, 87(4), pp. 520-544.

Cameron, A. C. and P. K. Trevidi (2005), Microeconometrics.Methods and Applications, Cambridge University Press.

Engel, D. V. Proecher and Ch. M. Schmidt (2013), “Does Firm Heterogeneity Affect Foreign Market Entry and Exit Symmetrically? Empirical Evidence for French Firms", Journal of Economic Behavior \& Organization, 85, pp. 35-47.

Helpman, E. , M. Melitz and S. R. Yeaple (2004), "Export versus FDI with Heterogeneous Firms", American Economic Review, 94, pp. 300-16

Klinert, J. and F. Toubal (2010), “Gravity for FDI”, Review of International Economics. 18(1), pp. 1-13.

Marti, J, Alguacil, M and V. Orts (2015) "Decisions of Heterogeneous European Firms in a Multicountry Framework", MPRA Paper No. 65450,http://mpra.ub.unimuenchen.de/65450/

Mayer, T. and S. Zignano (2011) "Notes on CEPII's distances measures: The GeoDist database”, CEPII Working Paper, №2011-25, December 2011

Melitz, M.(2003), "The Impact of Trade on Intra-Industry Reallocations and Aggregate Industry Productivity”, Econometrica 71, pp. 1695-1725.

Miguélez, E. and R. Moreno (2013) "Do Labour Mobility and Technological Collaborations Foster Geographical Diffusion? The Case of European Regions, Growth and Change 44, no. 2, pp. 321-354. 
OECD (2005) OECD Handbook on Economic Globalization Indicators, OECD Publishing.

Paniagua, J. (2016) “A Note on Implementing Gravity Datasets with Abundant Zeros", Economics Bulletin, 36(1) pp. 627-632.

Pinto-Ribeiro,S., S.Menghinello and K. Backer (2010) "The OECD ORBIS Data Base: Responding to the Need for Firm-Level Micro-Data in the OECD”. Statistics Directorate, Working Paper 2010/1.

Santos Silva and Tenreyro (2006) "The Log of Gravity", The Review of Economics and Statistics, 88(4), pp. 641-658.

Yeaple, S. R. (2009) "Firm Heterogeneity and the Structure of U.S. Multinational Activity", Journal of International Economics , 78 pp. 206-215. 
Figure 1

Distribution of the number of subsidiary firms owned by a parent firm in a given market

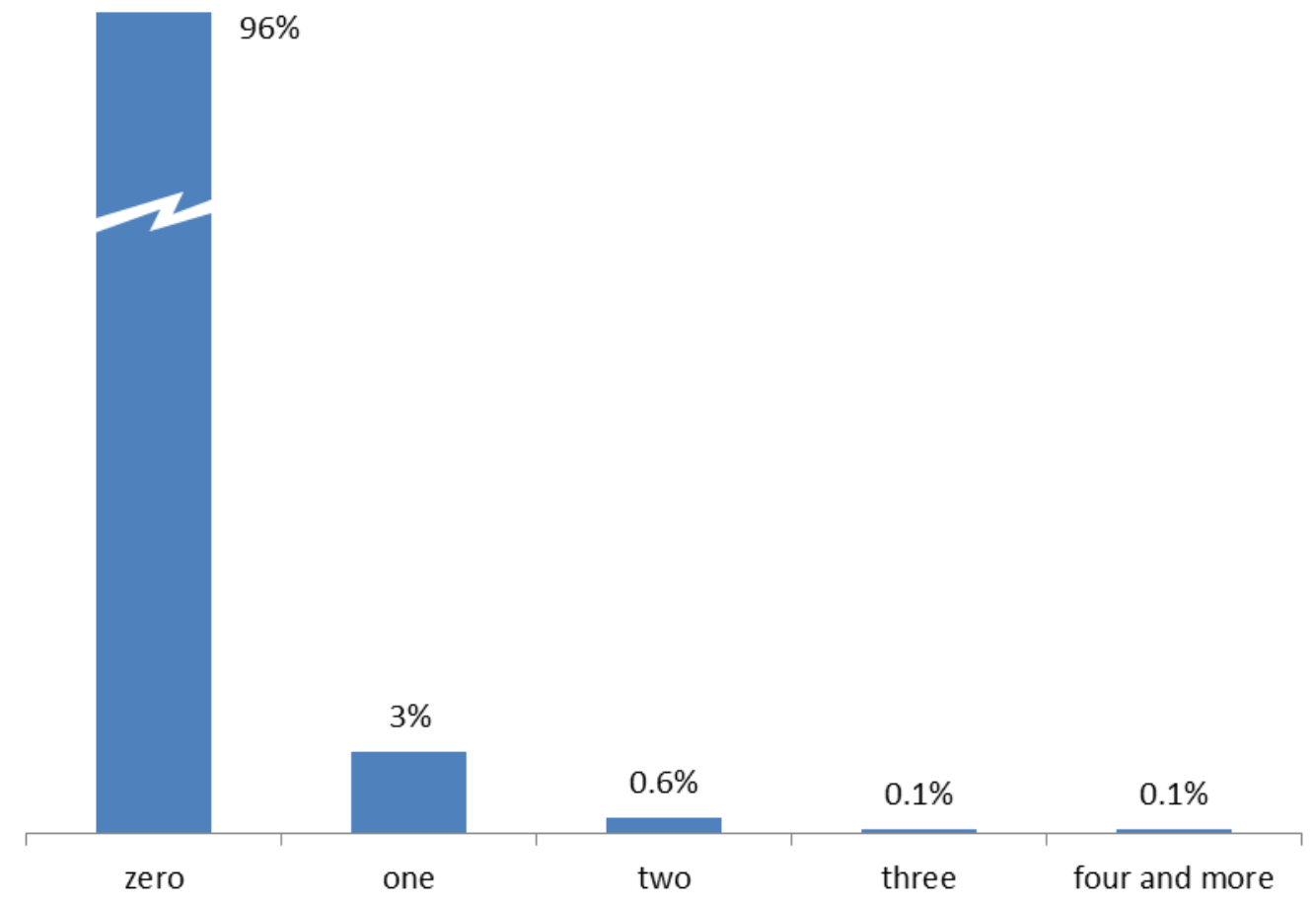




\section{Figure 2}

Parent firm's productivity and size levels according to the number of subsidiary firms owned by multinational firms (Index: zero subsidiaries=100)

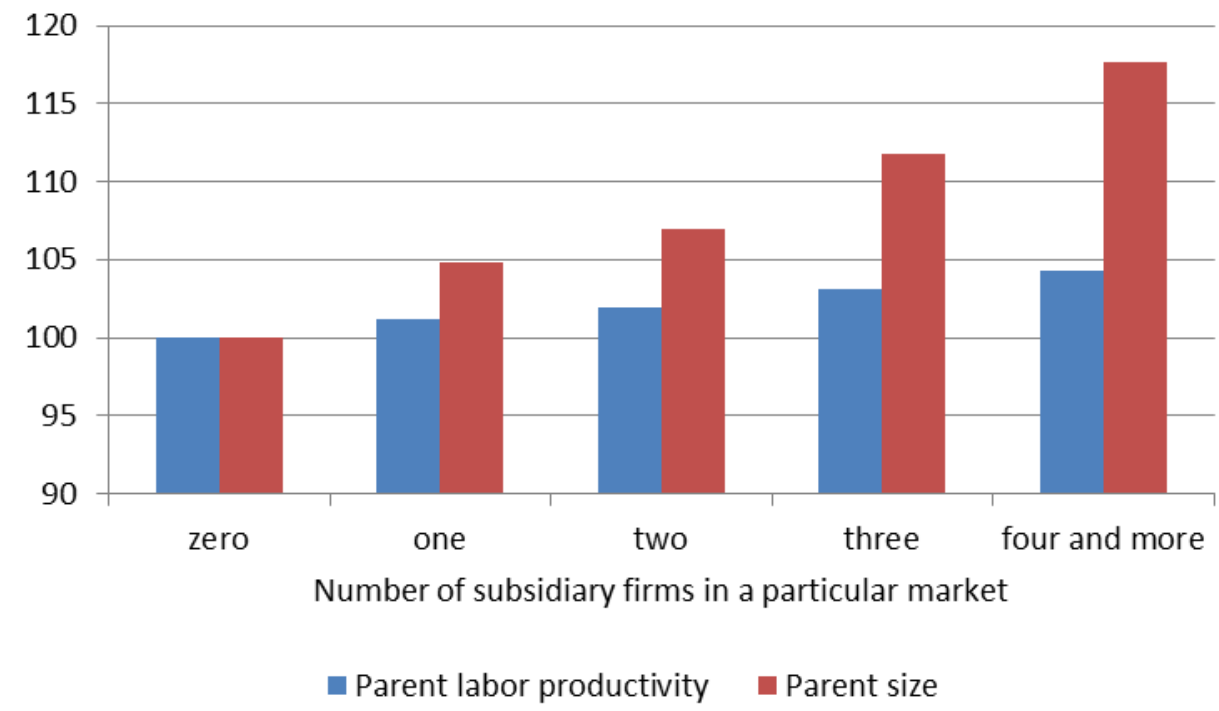


Figure 3

Scatter diagram of parent firm's average productivity vs. average number of subsidiary firms by countries (including markets with zero subsidiaries in the average calculation)

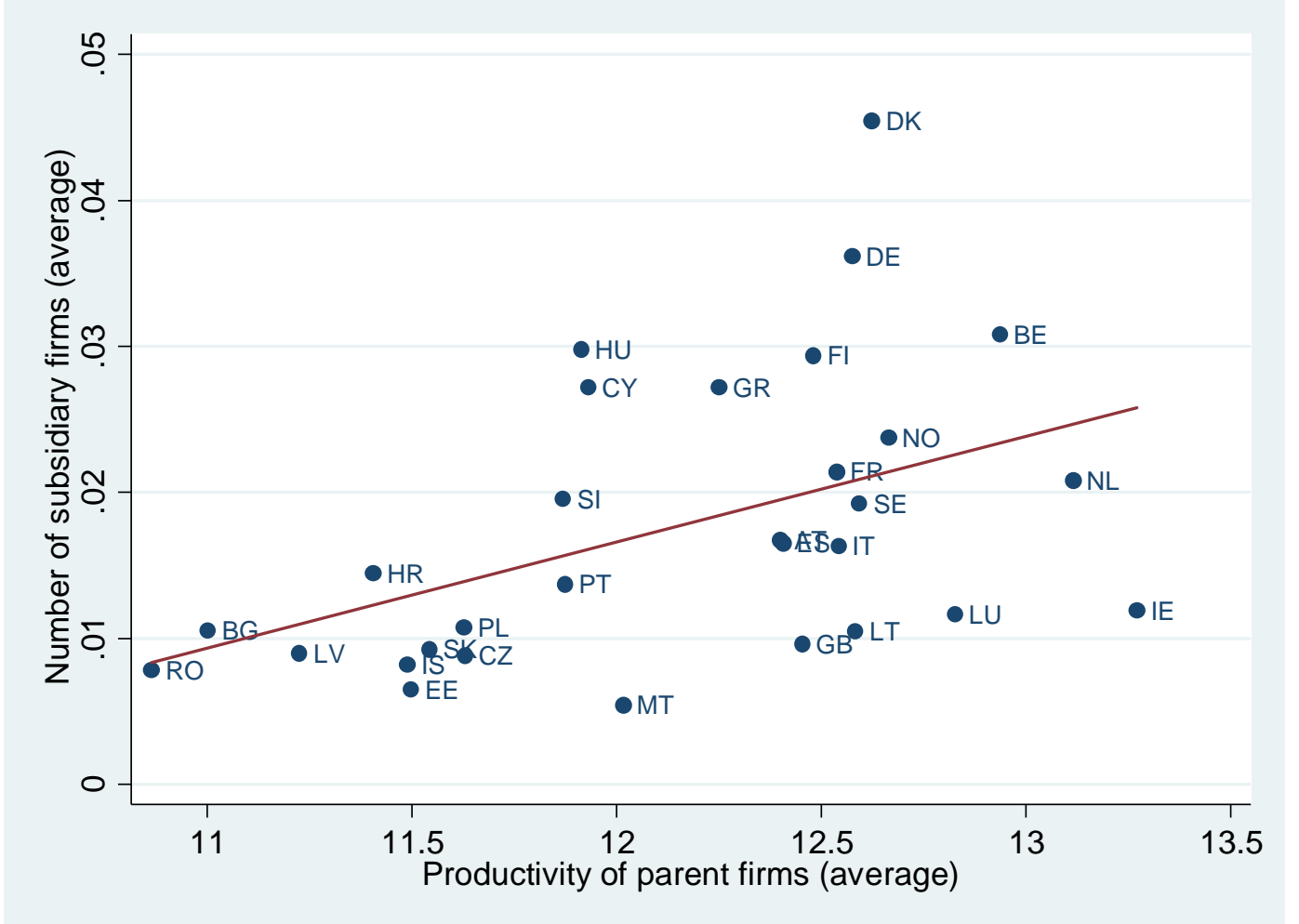

Note: Letters are ISO country codes 
Table 1

Number of firms and countries in the sample

\begin{tabular}{lcccccc}
\hline & \multicolumn{2}{c}{$\begin{array}{c}\text { Parent firms are Immediate } \\
\text { owners of subsidiaries }\end{array}$} & \multicolumn{3}{c}{ Parent firms are Global } \\
& (a) & (b) & (c) & (a) & (b) & (c) \\
\hline Number of: & 15,055 & 14,934 & 12,057 & 4,134 & 4,073 & 3,240 \\
\hline Parent firms & 55,007 & 53,583 & 46,171 & 21,608 & 20,496 & 17,408 \\
\hline Subsidiary firms & 30 & 30 & 30 & 30 & 30 & 30 \\
\hline $\begin{array}{l}\text { Home countries } \\
\text { (origin of the FDI) }\end{array}$ & 183 & 71 & 71 & 173 & 60 & 60 \\
\hline Host countries & 1830 & & &
\end{tabular}

Notes:

(a) Initial sample.

(b) Excluding host countries which do not have at least 50 affiliate firms.

(c) Requiring that the variable Sales of parent firm is available. 
Table 2

The scope of European multinational firms: propensity to invest in a foreign market $\left(D N_{f t j}\right)$ as a function of parent firm's labor productivity.

\begin{tabular}{|c|c|c|c|c|}
\hline & \multicolumn{4}{|c|}{ Parent firms are: } \\
\hline & Immedia & e owners & Global ul & ate owners \\
\hline Parent size $\left(\ln S_{f t j}\right)$ & $\begin{array}{l}0.0108 * * * \\
(0.0001)\end{array}$ & & $\begin{array}{l}0.0218^{* * *} \\
(0.0004)\end{array}$ & \\
\hline Parent labor productivity $\left(\ln L P_{f i j}\right)$ & & $\begin{array}{l}0.0070 * * * \\
(0.0003)\end{array}$ & & $\begin{array}{l}0.0151 * * * \\
(0.0008)\end{array}$ \\
\hline Home country fixed effect & Yes & Yes & Yes & Yes \\
\hline Host country fixed effect & Yes & Yes & Yes & Yes \\
\hline Industry fixed effect & Yes & Yes & Yes & Yes \\
\hline R-Squared & 0.0768 & 0.0693 & 0.1082 & 0.0879 \\
\hline N. of observations & 843,994 & 760,413 & 191,162 & 175,586 \\
\hline N. of home countries & 30 & 30 & 30 & 30 \\
\hline N. of host countries & 71 & 71 & 60 & 60 \\
\hline N. of parent firms & 12,057 & 10,863 & 3,240 & 2,976 \\
\hline
\end{tabular}

Notes: in parentheses are standard errors robust to heteroskedasticity of OLS estimated coefficients. Superscripts $* * *, * *$ and $*$ indicate significance at the 1,5 and 10 percent confidence levels, respectively. 


\section{Table 3}

The scope of European multinationals: the number of subsidiary firms $\left(N_{f t f}\right)$ as a function of parent firms' productivity. Alternative estimators.

\begin{tabular}{|c|c|c|c|c|}
\hline & PML & NBML & ZIPML & ZINBML \\
\hline $\begin{array}{l}\text { Parent firm's productivity } \\
\left(\ln L P_{f i f}\right)\end{array}$ & $\begin{array}{c}0.2359 * * * \\
(0.0090)\end{array}$ & $\begin{array}{c}0.2618^{* * *} \\
(0.0090)\end{array}$ & $\begin{array}{c}0.1205^{* * *} \\
(0.0113)\end{array}$ & $\begin{array}{c}0.1130^{* * *} \\
(0.0093)\end{array}$ \\
\hline Constant & $\begin{array}{c}-6.6449 * * * \\
(0.2090)\end{array}$ & $\begin{array}{c}-6.9114 * * * \\
(0.1944)\end{array}$ & $\begin{array}{c}-1.4042^{* * *} \\
(0.3776)\end{array}$ & $\begin{array}{c}-1.7355^{* * *} \\
(0.2506)\end{array}$ \\
\hline Home country fixed effect & Yes & Yes & Yes & Yes \\
\hline Host country fixed effect & Yes & Yes & Yes & Yes \\
\hline Industry fixed effect & Yes & Yes & Yes & Yes \\
\hline \multicolumn{5}{|l|}{ Model predicting zeros: } \\
\hline Total number of subsidiaries & & & $\begin{array}{c}-0.2439 * * * \\
(0.0047)\end{array}$ & $\begin{array}{c}-0.2997^{* * *} \\
(0.0056)\end{array}$ \\
\hline GDP host country & & & $\begin{array}{c}-0.5925 * * * \\
(0.0138)\end{array}$ & $\begin{array}{c}-0.6516^{* * *} \\
(0.0123)\end{array}$ \\
\hline Distance & & & $\begin{array}{c}0.9617^{* * *} \\
(0.0201)\end{array}$ & $\begin{array}{c}1.0803^{* * *} \\
(0.0184)\end{array}$ \\
\hline Home country FE & & & Yes & Yes \\
\hline Industry FE & & & Yes & Yes \\
\hline Overdispersion $(\alpha)$ & & $\begin{array}{c}5.4969 * * * \\
(0.1280)\end{array}$ & & $\begin{array}{c}0.7519 * * * \\
(0.179)\end{array}$ \\
\hline $\begin{array}{l}\text { LR of } \alpha=0 \\
\text { (p-value) }\end{array}$ & & $\begin{array}{c}35,000 \\
(0.0000)\end{array}$ & & $\begin{array}{l}7827.06 \\
(0.000)\end{array}$ \\
\hline $\begin{array}{l}\text { Vuong test } \\
\text { (p-value) }\end{array}$ & & & $\begin{array}{c}42.29 \\
(0.000)\end{array}$ & $\begin{array}{l}77.87 \\
(0.000)\end{array}$ \\
\hline N. of observations & 760,413 & 760,413 & 749,550 & 749,550 \\
\hline Log-likelihood & $-146,553.8$ & $-129,143.6$ & $-114,398.2$ & $-110,484.7$ \\
\hline
\end{tabular}

Notes: in parentheses are standard errors robust to heteroskedasticity of estimated coefficients. Superscripts $* * *$, ** and * indicate significance at the 1,5 and 10 percent confidence levels, respectively. PPML, Poisson pseudomaximum likelihood; NMPML, negative binomial maximum likelihood; ZIPML, zero-inflated maximum likelihood; ZINBML, zero-inflated negative binomial maximum likelihood. 


\section{Table 4}

The scope of European multinational firm by countries: propensity to invest in a foreign market as a function of parent labor productivity (Parent firms: Immediate owners)

\begin{tabular}{|c|c|c|c|c|c|c|}
\hline $\begin{array}{l}\text { Estimation } \\
\text { method }\end{array}$ & Explanatory variable & France & Germany & $\begin{array}{l}\text { Great } \\
\text { Britain }\end{array}$ & Italy & Spain \\
\hline \multicolumn{7}{|c|}{ Dependent variable: Propensity to invest in a foreign market $\left(D N_{f i f}\right)$} \\
\hline OLS & Parent size $\left(\ln S_{f i f}\right)$ & $\begin{array}{c}0.0125^{* * *} \\
(0.0004)\end{array}$ & $\begin{array}{c}0.0236^{* * * *} \\
(0.0005)\end{array}$ & $\begin{array}{l}0.0007 * \\
(0.0004)\end{array}$ & $\begin{array}{c}0.0087^{* * *} \\
(0.0003)\end{array}$ & $\begin{array}{c}0.0074^{* * *} \\
(0.0004)\end{array}$ \\
\hline OLS & $\begin{array}{l}\text { Parent labor } \\
\text { productivity }\left(\ln L P_{f(j)}\right)\end{array}$ & $\begin{array}{c}0.0062^{* * *} \\
(0.0012)\end{array}$ & $\begin{array}{c}0.0130 * * * \\
(0.0009)\end{array}$ & $\begin{array}{c}0.0012 \\
(0.0008)\end{array}$ & $\begin{array}{c}0.0048 * * * \\
(0.0005)\end{array}$ & $\begin{array}{c}0.0044 * * * \\
(0.0008)\end{array}$ \\
\hline \multicolumn{7}{|c|}{ Dependent variable: Number of subsidiary firms $\left(N_{f f f}\right)$} \\
\hline ZIPPML & $\begin{array}{l}\text { Parent labor } \\
\text { productivity }\left(\ln L P_{f i f}\right)\end{array}$ & $\begin{array}{c}0.1270^{* * *} \\
(0.0257)\end{array}$ & $\begin{array}{c}0.1690 * * * \\
(0.0266)\end{array}$ & $\begin{array}{c}0.0298 \\
(0.0380)\end{array}$ & $\begin{array}{c}0.1099 * * * \\
(0.0201)\end{array}$ & $\begin{array}{c}0.0925 * * * \\
(0.0247)\end{array}$ \\
\hline ZINBPML & $\begin{array}{l}\text { Parent labor } \\
\text { productivity }\left(\ln L P_{f i f}\right)\end{array}$ & $\begin{array}{c}0.1305^{* * *} \\
(0.0261)\end{array}$ & $\begin{array}{c}0.1224 * * * \\
(0.0184)\end{array}$ & $\begin{array}{c}0.0304 \\
(0.0381)\end{array}$ & $\begin{array}{c}0.1124 * * * \\
(0.0204)\end{array}$ & $\begin{array}{c}0.0951^{* * *} \\
(0.0250)\end{array}$ \\
\hline
\end{tabular}

Notes: The elements of this table provide the coefficients $\beta_{1}$ estimated from equations (1) and (2). Each element corresponds to a different regression. All the regressions contain host country fixed effects and industry fixed effects. In parentheses are standard errors robust to heteroskedasticity of estimated coefficients. Superscripts ***, ** and ${ }^{*}$ indicate significance at the 1,5 and 10 percent confidence levels, respectively. ZIPML, zero-inflated maximum likelihood; ZINBML, zero-inflated negative binomial maximum likelihood. 


\section{Table 5}

The scale of European multinational firms: the size of subsidiary firms as a function of their parent firm's characteristics

\begin{tabular}{|c|c|c|c|c|}
\hline & \multicolumn{4}{|c|}{ Parent firms are: } \\
\hline & Immedia & e owners & Global ultin & te owners \\
\hline Parent size $\left(\ln S_{f i f}\right)$ & $\begin{array}{c}0.2796 * * * \\
(0.0082)\end{array}$ & & $\begin{array}{c}0.2622 * * * \\
(0.0123)\end{array}$ & \\
\hline Parent labor productivity $\left(\ln L P_{f i f}\right)$ & & $\begin{array}{c}0.3127^{* * * *} \\
(0.0188)\end{array}$ & & $\begin{array}{c}0.2764^{* * *} \\
(0.0292)\end{array}$ \\
\hline Home country fixed effect & Yes & Yes & Yes & Yes \\
\hline Host country fixed effect & Yes & Yes & Yes & Yes \\
\hline Industry fixed effect & Yes & Yes & Yes & Yes \\
\hline R-Squared & 0.2782 & 0.2322 & 0.3216 & 0.2917 \\
\hline N. of observations & 18,739 & 17,121 & 7,137 & 6,623 \\
\hline
\end{tabular}

Notes: in parentheses are standard errors robust to heteroskedasticity of OLS estimated coefficients. Superscripts $* * *, * *$ and $*$ indicate significance at the 1,5 and 10 percent confidence levels, respectively.

Table 6

The scale of European multinational firms by countries: the size of subsidiary firms as a function of their parent firm's characteristics (Parent firms: Immediate owners)

\begin{tabular}{lcccc}
\hline Explanatory variable: & France & Germany & Italy & Spain \\
\hline Parent size $\left(\ln S_{f i f}\right)$ & $0.4613^{* * *}$ & $0.2810^{* * *}$ & $0.3527^{* * *}$ & $0.3776^{* * *}$ \\
& $(0.0323)$ & $(0.0213)$ & $(0.0321)$ & $(0.0442)$ \\
Parent labor productivity $\left(\ln L P_{f i f}\right)$ & $0.4206^{* * *}$ & $0.1584^{* * *}$ & $0.4901^{* * *}$ & $0.2894^{* * *}$ \\
& $(0.0829)$ & $(0.0420)$ & $(0.0523)$ & $(0.0895)$ \\
\hline
\end{tabular}

Notes: Each element of this table reproduces the coefficient $\beta_{1}$ of equations (3) estimated by OLS in a different regression. All the regressions contain host country fixed effects and industry fixed effects. In parentheses are standard errors robust to heteroskedasticity of estimated coefficients. Superscripts $* * *, * *$ and $*$ indicate significance at the 1, 5 and 10 percent confidence levels, respectively. 